\title{
ON THE GROUND
}

\section{A disappearing drylands icon? White rhinoceros conservation and the need for public private partnerships.}

\author{
Angelo P. Pernetta
}

Biogeography and Ecology Research Group, University of Brighton in Hastings, Priory Square, Priory Street, Hastings TN34 1EA, United Kingdom.E-mail:a.pernetta@brighton.ac.uk

Reaching a "tipping point" is probably an overused phrase in the context of biodiversity conservation, running the risk of diluting its impact. Nonetheless, having recently returned from a wildlife reserve in South Africa's bushveld, I believe that the global population of southern white rhinoceros (Ceratotherium simum simum, Figure 1) is rapidly approaching such a juncture.

South Africa's dryland habitats have been integral in helping create one of the nations most lauded conservation success stories. In the space of a hundred years South Africa has been pivotal in recovering the global population of white rhino from a historical low of just one population comprising less than 50 breeding individuals by the end of the $19^{\text {th }}$ century (Emslie \& Brooks, 2002), to the most recent global population estimate of 20,404 individuals, of which 83\% are found within South Africa's borders (Emslie, 2013). However, concurrent with this huge conservation success has been an exponential increase in the numbers of rhino illegally poached since the millennium (Figure 2), fuelled by rapidly increased demand from an increasingly affluent Southeast Asian market (Milliken and Shaw, 2012). By the end of 2013 over 1000 rhino had been poached in that year alone; an average 
of 3 individuals per day. By the $17^{\text {th }}$ of April 2014 the South Africa Department for Environmental Affairs had recorded a total of 294 for this year (Figure 2) indicating there will be broadly comparable numbers of rhino poached this year too. Predictive modelling based approaches suggest, subject to sustained poaching at these levels, the single largest remaining population of white rhino in Kruger National Park will be in detectable decline by 2016 (Ferreira et al., 2012). All this goes on despite the species being listed in Appendix 1 of the Convention on International Trade in Endangered Species (CITES) in 1977, effectively banning all international trade in rhino and their derivative products.

So why are we seeing continued rises in this illegal trade? Put simply, gram for gram the black market price of Rhino horn exceeds that of gold, diamonds, or cocaine (Biggs et al., 2013). This situation is undoubtedly fuelled by human desire. Increasing rarity leads to increasing demand and therefore increasing value, resulting in a situation where it remains economically viable to utilise a diminishing resource; sensu the anthropogenic alee effect (Courchamp et al., 2006).

So what is the solution? Opinion within the conservation community is divided as to how this might be averted. On the one hand some proponents would argue that a more effective campaign of awareness and legal enforcement could provide the solution by reducing consumer demand (Litchfield, 2013) for what is arguably the world's most expensive placebo. On the other, those seeking to address the issue through sustainable utilisation would argue that a highly regulated, independently controlled legal trade should be established to supply demand through the sale of existing stock piles and de-horning of live animals (Biggs et al., 2013). Whilst both camps have the same ultimate goal of conserving white rhino populations, only one addresses the fact that approximately $25 \%$ of the white rhino population is currently maintained on private land in South Africa (Biggs et al., 2013). 
Conservation of dryland habitats and its constituent biodiversity has arguably become a privately owned affair in South Africa. At a national level, it is estimated that 9000 'game ranches' and a further 15,000 ranches with both wildlife and livestock have been established (Cousins et al. 2008). These privately owned enterprises represent $16.8 \%$ of national land usage; nearly three times $(6.1 \%)$ the land protected in national and provincial parks (Bothma and Von Bach, 2009). As commercial operations, these reserves have the potential to polarise opinion in terms of the underlying ethos for their establishment. However, what is clear is that by their expanding nature, they are playing an increasingly important role in the future of conservation in South Africa (Cousins et al. 2009).

It is at this point that I come back to my recent experience in South Africa. Talking to the owners and managers of one such commercial conservation enterprise, I quickly realised the financial and possibly more importantly, emotional cost this poaching crisis is having on them. In an effort to prevent poaching from occurring, staff on this particular reserve employed more workers, ramped up security patrols during the day and at night and invested in heightened security measures such as camera traps on points of entry into reserves and increased maintenance regimes on the boundary fences. All of this work is fuelled by the desire to prevent illegal poaching resulting in their rhino being another statistic to mourn. Living in constant fear of this threat means a cow herder too close to their boundary fence or a helicopter flying over the reserve is always assumed to be a threat and means constantly living on the edge. Thankfully their hard work and devotion to their reserve has protected their rhino so far.

The question they and many other private landowners face is how long can they continue to do this? Given the highly organised nature of the criminal activity surrounding rhino poaching in South Africa, secrecy has become an important way to maintain security (hence not naming the particular reserve in this article), hindering the economic potential of keeping 
privately owned rhino. Fundamental to private ownership is the need to make conservation "pay" through revenue streams such as ecotourism and whilst this revenue stream is ongoing, the increasing security costs of maintaining the status quo could put the economic feasibility of having rhino on a private reserve in jeopardy. This leads me to my concluding thought... should we, the public, be doing as much to support these private organisations, as we do for National Parks in the fight against rhino poaching? Should we be more accepting of the potential of a legalised, controlled trade in sustainably harvested rhino horn? Given the global importance of these private reserves for rhino, whatever we do, it is clear that we must support landowners in their on going battle.

\section{Acknowledgements}

I am extremely grateful to the owners, staff and animals of the reserve that inspired this article. I hope that I have managed to retain their anonymity whilst writing this work. I am also grateful to Dr Maureen Berg for allowing me to use her photograph.

\section{References}

Biggs, D., Courchamp, F., Martin, R. and Possingham, H. P. 2013. Legal Trade of Africa's Rhino Horns. Science 339:1038-1039.

Bothma, J du P. and Von Bach, S.H. 2009. Economic aspects of wildlife production in southern Africa In Game Ranch Management, $5^{\text {th }}$ Edition, edited by J. Du P. Bothma and J.G. du Toit. Pretoria: Van Schaik. 
Courchamp, F., Angulo, E., Rivalan, P., Hall, R.J., Signoret, L., Bull, L and Meinard, Y. (2006) Rarity Value and Species Extinction: The Anthropogenic Allee Effect. PLoS Biology 4(12): e415. doi:10.1371/journal.pbio.0040415.

Cousins, J.A., J.P. Sadler, and J. Evans. 2008. Exploring the role of private wildlife ranching as a conservation tool in South Africa: stakeholder perspectives. Ecology and Society 3(2): $1-34$.

Emslie, R.H., 2013. African Rhinoceroses - Latest trends in rhino numbers and poaching. African indaba, e-newsletter 11(2): 11-12

Emslie, R. \& Brooks, M. 2002. How many southern white rhinos were there? A response to Kees Rookmaaker. Pachyderm 33: 100-101.

Ferreira, S.M., Botha, J.M., Emmett, M.C. 2012 Anthropogenic Influences on Conservation Values of White Rhinoceros. PLoS ONE 7(9): e45989. doi:10.1371/journal.pone.0045989

Litchfield, C.A. 2013. Rhino poaching: apply conservation psychology. Science 340: 1168.

Milliken, T. and Shaw, J. 2012. The South Africa-Viet Nam Rhino Horn Trade Nexus: A deadly combination of institutional lapses, corrupt wildlife industry professionals and Asian crime syndicates. TRAFFIC, Johannesburg, South Africa. 


\section{Figure titles}

Figure 1. Two southern white rhinoceroses (Ceratotherium simum simum) at Pilanesberg

National Park, South Africa. Photograph reproduced with permission from Dr Maureen Berg (University of Brighton).

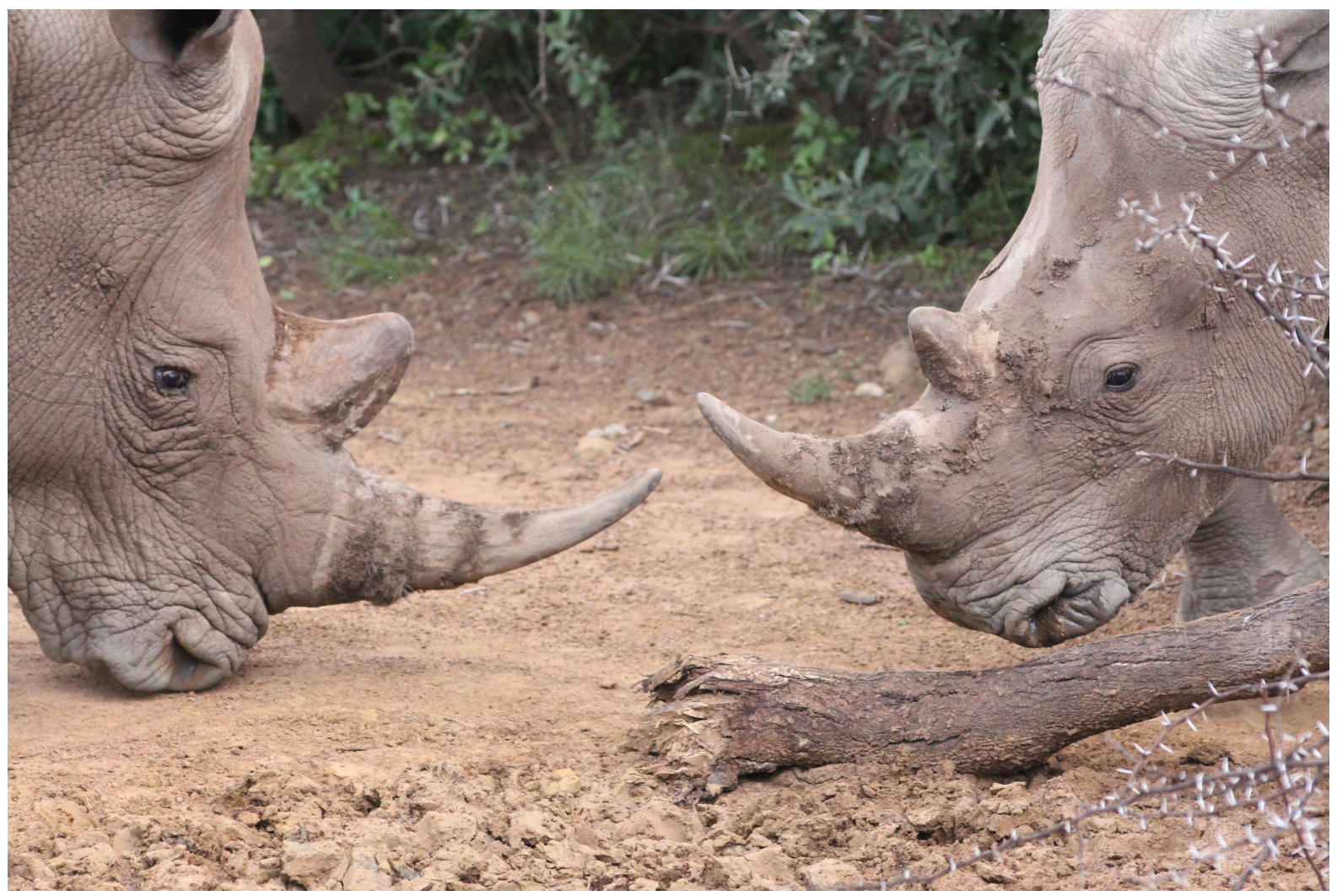


Figure 2. The annual recorded cases of illegal rhinoceros poaching in South Africa. Data for 2014 is up until $17^{\text {th }}$ April (Data source:

http://www.savetherhino.org/rhino_info/poaching_statistics)

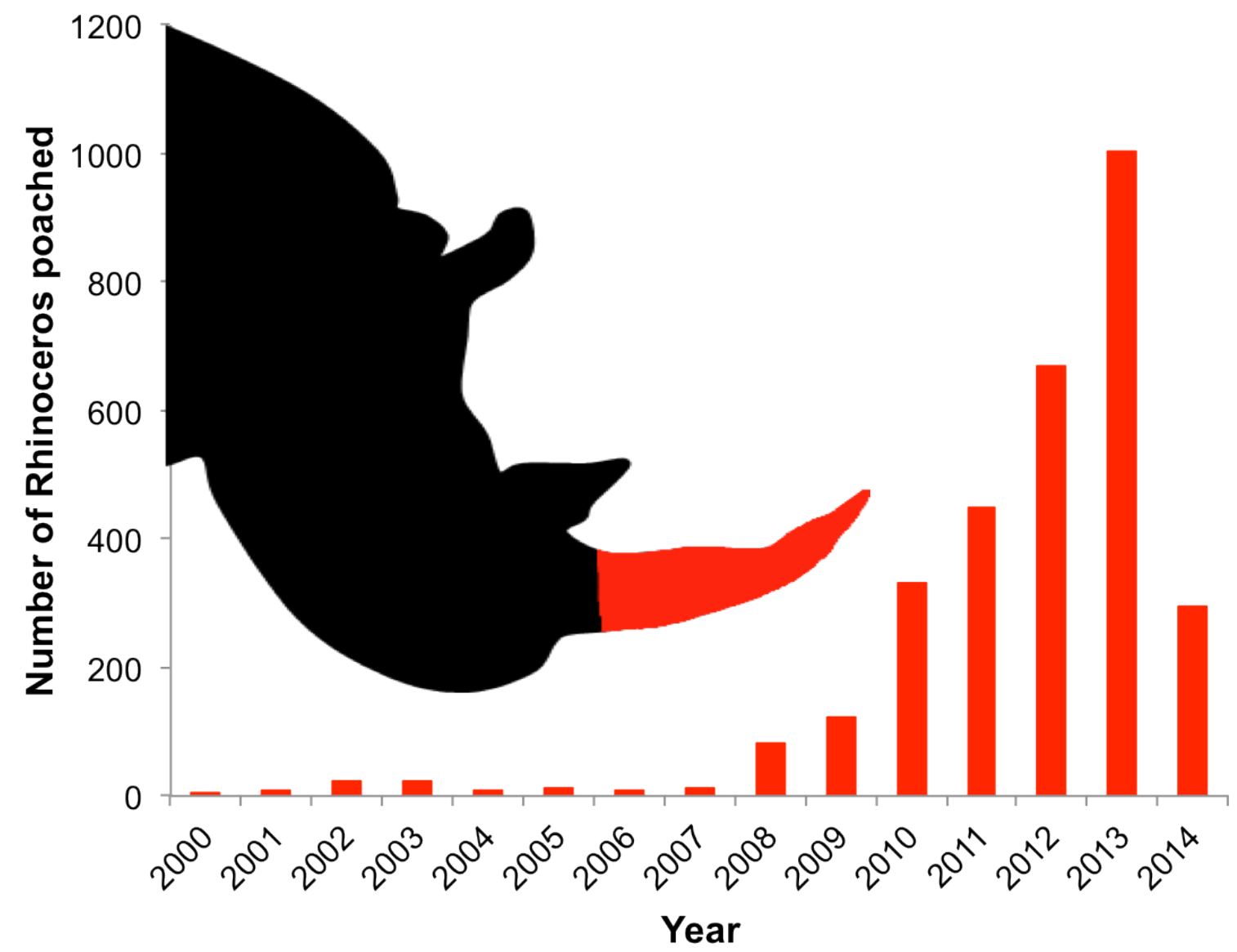

